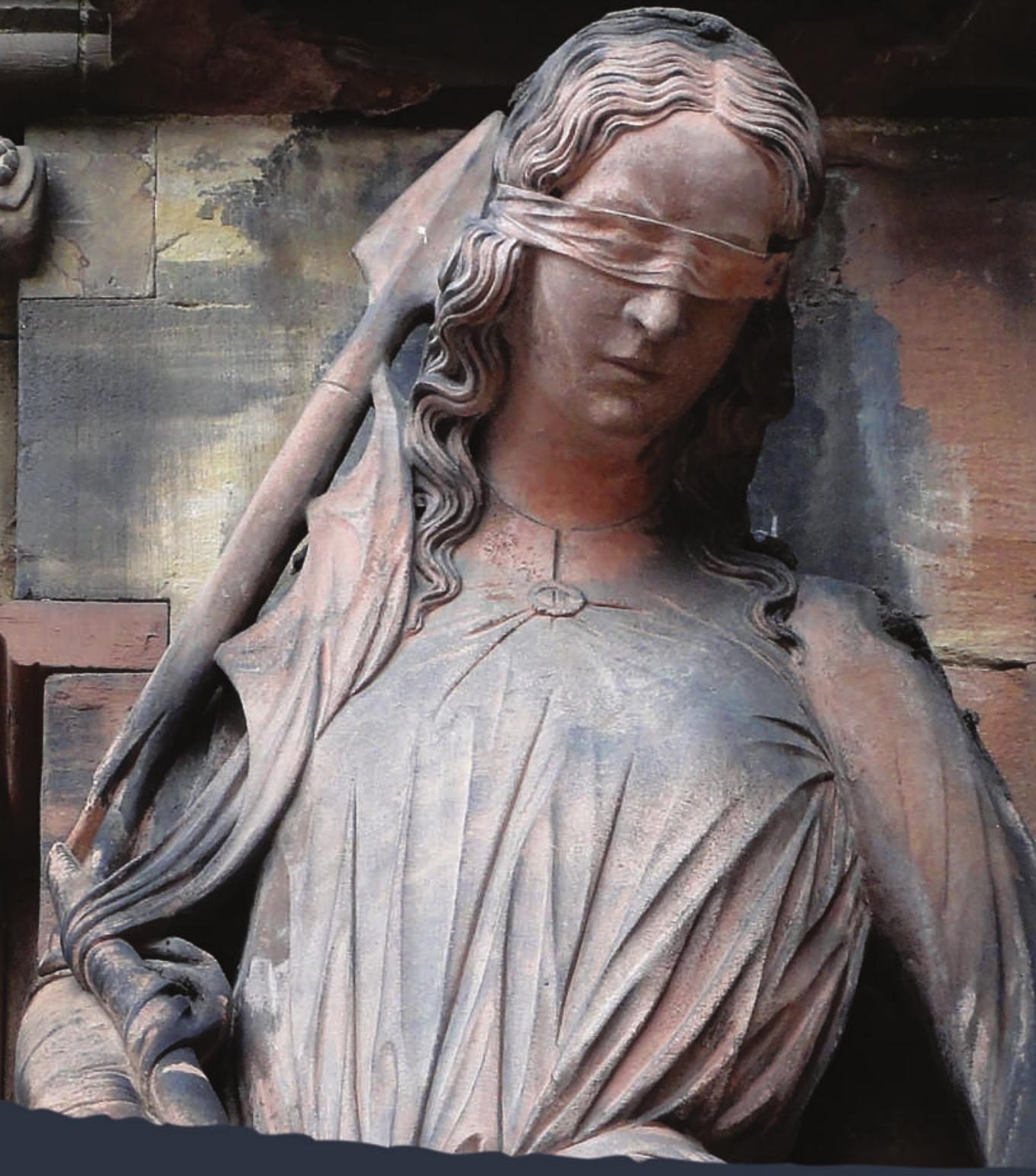

\title{
SIMHA GOLDIN
}

APOSTASY AND JEWISH

IDENTITY IN HIGH MIDDLE

AGES NORTHERN EUROPE

'ARE YOU STILL MY BROTHER?' 
Apostasy and Jewish identity

in High Middle Ages Northern Europe

\section{MANCHESTER \\ 1824}

Manchester University Press 
Simha Goldin - 9781526129345

Downloaded from manchesterhive.com at 04/26/2023 05:39:52AM 


\title{
Apostasy and Jewish identity in High Middle Ages Northern Europe
}

\author{
'Are you still my brother?'
}

Simha Goldin

Translated by Jonathan Chipman

Manchester University Press 
The right of Simha Goldin to be identified as the author of this work has been asserted by him in accordance with the Copyright, Designs and Patents Act 1988.

Published by Manchester University Press

Altrincham Street, Manchester M1 7JA, UK

and Room 400, 175 Fifth Avenue, New York, NY 10010, USA

www.manchesteruniversitypress.co.uk

British Library Cataloguing-in-Publication Data

A catalogue record for this book is available from the British Library

Library of Congress Cataloging-in-Publication Data applied for

ISBN 9780719095771 hardback

First published 2014

The publisher has no responsibility for the persistence or accuracy of URLs for any external or third-party internet websites referred to in this book, and does not guarantee that any content on such websites is, or will remain, accurate or appropriate.

\section{Typeset}

by Carnegie Book Production, Lancaster 